\title{
Development of Science Learning Module Based on Laboratory Activity in Electricity Topic on Student Learning Outcomes
}

Arisa Desfiyani", Muhammad Zaini, Suryajaya

Masters Program of Natural Sciences Teaching, Lambung Mangkurat University, Banjarmasin, Indonesia

\author{
DOI: 1 10.36348/jaep.2020.v04i11.002 $\quad$ | Received: 29.10.2020 | Accepted: 11.11.2020 | Published: 17.11 .2020 \\ *Corresponding author: Arisa Desfiyani
}

Abstract

The achievement in the science national examination of SMPN 1 Kertak Hanyar was low. The laboratory has not been optimally used for supporting learning activities. The main books used were not so interesting that they influenced the teaching and learning process. Development research was needed to get a good quality of science learning module based on laboratory activity. This research was aimed to (1) evaluate module validity; (2) evaluate module practicality, and (3) evaluate module effectiveness. The development research used Tessmer's formative evaluation design. The research subjects were grade IX students of SMPN 1 Kertak Hanyar who were selected by convenience sampling of the probability method. Data obtained through research were those of the students' learning achievements including cognitive learning achievement, science process skills, critical thinking skills, and critical thinking abilities. The results of the research indicated that the module based on laboratory activity can be used in learning activities because it has the criteria: (1) valid, mean 3,83 based on six criteria, such as design, language, and organization, material, format, presentation, supporting innovation and improving the quality of teaching and learning activities; (2) practical, based on five criteria, such as content attractiveness, appearance attractiveness, ease of material description, ease of illustration or image, and ease of practicum steps, and (3) effective, based on four criteria, such as cognitive learning achievement, science process skills, critical thinking skills, and critical thinking abilities.

Keywords: Learning modules, laboratory activities, electricity, learning outcomes.

Copyright () 2020 The Author(s): This is an open-access article distributed under the terms of the Creative Commons Attribution 4.0 International License (CC BY-NC 4.0) which permits unrestricted use, distribution, and reproduction in any medium for non-commercial use provided the original author and source are credited.

\section{INTRODUCTION}

Implications of Chapter I Article 1 paragraph (1) of Law No. 20 of 2003 concerning the National Education System is education that must be carried out in a planned manner, educators who must involve students to actively develop their potential, and educators who must direct students to have religious spiritual strength, self-control, personality, intelligence, noble character, as well as the skills needed by himself, society, the nation and the country. Every educator must know and understand all aspects of education that have been standardized, so that they can become a reference or guide in carrying out education.

Education in the $21^{\text {st }}$ century is closely related to the digital world. All information can be accessed via the internet, but there is no guarantee that the information presented is correct. Information seekers are required to be smart in choosing and sorting. Of course, choosing and sorting information cannot be done carelessly, there must be an underlying idea to conclude that the information to be retrieved is accurate and credible information. Through this thinking, individuals will try to prove that the information received is truly valid and can be accounted for [1].

There are many kinds of thinking patterns that need to be developed, from basic level thinking to higher-order or complex thinking. Conway in Kuswana [2] explains that thinking skills involve six types of thinking, namely metacognition, critical thinking, creative thinking, cognitive processes (problem solving and decision making), core thinking skills, and understanding the role of knowledge content. Critical thinking is the basis of another mindset. That is, critical thinking needs to be mastered first before reaching other thinking patterns.

Critical thinking needs to be trained and developed in each individual, even from the most basic education. Individuals who are accustomed to critical thinking will be able to solve problems with the best decisions based on logical, analytical, and systematic thought processes. When taking education, critical 
Arisa Desfiyani et al., J Adv Educ Philos, Nov, 2020; 4(11): 446-452

thinking is needed in stabilizing goals, determining ways that can be used to realize these goals, considering the consequences that may arise as a result of the methods used, testing assumptions, making conclusions, and evaluating the results of achievement [3].

Critical thinking skills can be developed through science learning. Science or natural science is a subject at the basic education level which is a combination of three branches of science, namely physics, biology, and chemistry. Science is a science that studies the universe which contains a series of concepts to be observed and experimented with so that we can live in this universe. Through science learning, students are invited to think to understand and master nature and carry out investigations or investigations to form knowledge [4].

Science knowledge and scientific concepts can be built through learning in the form of practicum carried out in the laboratory [5]. In the 2013 Curriculum, the laboratory is an integral part of teaching and learning activities. There are at least four reasons that strengthen the role of laboratories in learning in Science in accordance with the 2013 Curriculum, including: 1) practicum raises students' motivation to learn Science; 2) practicum develops basic scientific skills in conducting experiments; 3 ) practicum becomes a vehicle for learning the scientific approach approach in accordance with the 2013 Curriculum; and 4) practicum supports a more realistic explanation of the subject matter [6].

Through science learning, teachers should teach students to build their own knowledge. So that learning science is not only about being a product, but also about the process and application, not only about memorizing, but also about discovering. Science learning is not only emphasized on understanding concepts alone, but is also directed at the side effects of this learning, namely the emergence of science process skills, as well as critical thinking skills and abilities. These skills are very important to develop because they will shape the patterns of action of each individual in social life.

Based on the data on the achievement of the results of the National Examination (UN) for the 2016/2017 academic year, SMPN 1 Kertak Hanyar is ranked 104 out of 133 public and private SMP / MTs in Banjar district with an average score of 47.57. The average science score is 43.55 and is ranked 101. The average science score in this school is still lower than the average science score at the district level, which is 51.04. The materials tested at the UN that year can be grouped into five main subjects, namely: (1) measurement, substance, and their properties; (2) mechanics and the solar system; (3) wave, electricity, and magnetism; (4) living things and their environment; and (5) the structure and function of living things. The percentage of students who answered correctly on wave, electricity, and magnetism was the lowest with an achievement of 23.26. After further investigation, the lowest indicator is the indicator that students can sort the lights that are on from the brightest to the dimmest when a picture of 4 lights with known obstacles is mixed together. This indicator is part of the subject matter of electricity, which is about electric circuits (dynamic electricity).

Researchers made preliminary observations at SMPN 1 Kertak Hanyar by distributing questionnaires to students, starting from $7^{\text {th }}$ grade to $9^{\text {th }}$ grade, regarding the science learning process, as well as by conducting interviews with science teachers. Questionnaires are given to students to find out to what extent students like science lessons, what supporting books they use, how the book contains, and how their science learning so far. Regarding interest in science lessons, it is known that $68 \%$ of students do not and do not like science lessons, $24 \%$ like and quite like science lessons, and $8 \%$ really like science lessons. Students use a book supporting the work of a local publisher which contains a summary of the material and there are practice questions which they call LKS. In the book, there are several practicum activities, but only a few are carried out and most of them are biology science subject matter.

Interviews with four science teachers were conducted to find out what teaching materials were used, how the learning process took place, and how the evaluation was carried out. The teacher uses two main books, namely the 2013 Curriculum Science book from the Ministry of Education and Culture and a book called Student Worksheets (LKS). However, in its implementation, this student worksheet is more often used by students. The teaching materials used are still textual, in the form of a collection of materials. The material presented is incomplete and does not support students to find concepts through discovery. Colorless image presentation. The questions presented were only at the $\mathrm{C} 1$ to $\mathrm{C} 3$ levels so that it did not encourage students to think critically. During the lesson, students note the material presented by the teacher, so they are less active and enthusiastic, are reluctant to ask questions, and are reluctant to express opinions.

Science practicum activities at SMPN 1 Kertak Hanyar are quite often carried out, but the material that is practiced is mostly in the material of ScienceBiology. Electrical material that is commonly practiced is in static electricity experiments of electrically charged objects and making simple electrical circuits to distinguish series and parallel circuits without measuring the electric current or voltage. The background of the science teacher at SMPN 1 Kertak Hanyar who comes from chemistry education and biology education is one of the reasons why science- 
physics practicum is rarely done in schools. The researcher also asked the teacher about science process skills, critical thinking skills and abilities of students. The teacher explains that so far they have not specifically measured these skills so it is not known exactly how the quality of these skills is. Limited examples of assessment instruments make it difficult for teachers to measure these skills. The teacher chooses to assume that students who have good learning outcomes are students who have good science process skills, critical thinking skills and abilities.

The low results of national examinations on electrical materials may be due to the low science process skills, critical thinking skills and abilities of students. This may be overcome by implementing a laboratory activity based module in the learning process. Habibi in Hermita [7] explains that the learning process will run more optimally if it can maximize teaching materials that support students. Module [8] is a means to help students learn independently with or without assistance from the teacher. Through a laboratory activity-based module, students are expected to be able to build knowledge through discovery. Through practicum activities contained in the module, students are expected to be able to practice science process skills and critical thinking skills. Through higher order thinking skills (HOTS) questions, students are expected to be accustomed and trained in working on these questions and bring out critical thinking skills. This is in line with what was done by Yanti [9], Hermita [7], and Sanjaya [10] who developed laboratory-based learning modules, and Pratiwi [11] who developed modules to improve students' critical thinking skills.

\section{RESEARCH METHODS}

The research carried out was development research using Tessmer's formative evaluation model. The research steps include self-evaluations, expert reviews, one-to-one, small groups, and field tests. The research was conducted at SMPN 1 Kertak Hanyar for three months. The object of the experiment in this research is the science learning module based on the developed laboratory activity. The trial subjects in this study were: three experts at the expert review stage, three students at the one to one evaluation stage, six students at the small group stage, and 56 students in $9^{\text {th }}$ grade at SMPN 1 Kertak Hanyar in the 2018/2019 academic year. These 56 students were divided into two parts with each part selected to study using modules and the other part learning conventionally (without modules). Whereas in the one to one and small group stages three and six students were selected apart from the two classes who were considered capable of representing students with various student achievement abilities. The data needed and the instruments used in the study were: module validity, using a validation sheet and supported by a module readability sheet; practicality of the module, using student response sheets to the module; and the effectiveness of the module, using the learning outcome assessment sheet. The type of data to be obtained through this research is data on the validity, practicality, and effectiveness of the developed science module.

\section{RESEARCH RESULTS AND DISCUSSION Learning Tools Validity}

The validation carried out by these experts is related to the validity of the content which is divided into five aspects, namely module design, organization and language, material, format, and presentation. The results of the experts' analysis can be seen in the following table.

Table-1: Module validation results

\begin{tabular}{|l|l|l|l|l|l|}
\hline Assessment Aspects & \multicolumn{2}{|l|}{ Score of Each Assessment Aspect } & \multirow{2}{*}{ Average } & \multirow{2}{*}{ Category } \\
\cline { 2 - 5 } & Validator 1 & Validator 2 & Validator 3 & & \\
\hline Module design & 3.93 & 3.73 & 3.47 & 3.71 & Very valid \\
\hline Organization \& language & 4.00 & 4.00 & 3.50 & 3.83 & Very valid \\
\hline Theory & 3.92 & 3.92 & 3.92 & 3.92 & Very valid \\
\hline Format & 4.00 & 4.00 & 3.71 & 3.90 & Very valid \\
\hline Presentation & 4.00 & 3.50 & 3.75 & 3.75 & Very valid \\
\hline Supporting Innovation \& Quality Improvement of KBM & 4.00 & 4.00 & 3.50 & 3.83 & Very valid \\
\hline
\end{tabular}

Criteria for mean scores: $1-1.99=$ invalid; $2-2.99=$ quite valid; $3-3.99=$ valid; $4.00=$ very valid

The validation that is done is validation of the developed science learning module. The self-evaluated module draft is submitted to the validator to determine the validity value and improvements that need to be made to get a better module. Based on the six aspects of the assessment, the draft module 1 is categorized as very valid and can be used without revision. A very valid score for each indicator is obtained because in the module development process the researcher has compiled the module according to the instructional design rules. The validator gives good marks and provides suggestions for module improvement, including: a) making allusions of encouragement and motivational sentences at the beginning of each subchapter; b) make evaluation questions at the end of each section; c) use a more varied color; d) use questions at the beginning of each section to provoke the curiosity of students; e) use the image in the summary; and f) reduce the font size for the image source. Even though it has been declared very valid, the module 
development results still need improvement to produce modules that are more attractive to students to learn them, more in discussion of the material, and more practice questions in it.

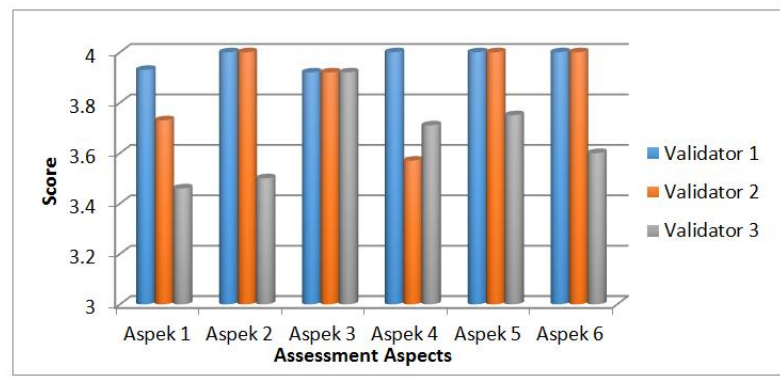

Fig-1: The results of the validator's assessment of the module

Description:

Aspect 1: module design

Aspect 2: organization and language

Aspect 3: material

Aspect 4: format

Aspect 5: presentation

Aspect 6: supporting innovation and improving the quality of teaching and learning activities
Through a laboratory activity-based science learning module, the learning atmosphere becomes more student-centered so as to encourage students to be more active. When students are active in learning activities, more knowledge will be absorbed. Through learning activities carried out by students in groups, it is hoped that interactions can be formed between group members to discuss with each other in solving problems. This is in line with the results of research by Misniyati et al., [12] who developed worksheets and obtained valid results (ranging from 75\%-83\%) and Suryawati et al., [13] who reported that scientific approach-based worksheets have a very valid and valid category on pedagogic, construction, technical and thinking skills.

\section{Practicality of Learning Devices}

Students are given an assessment sheet to find out their response to the developed module that has been used during the learning process on the electrical circuit material at the end of the field test activity. The results of the student response assessment are presented in the following table.

Table-2: The results of the assessment of student responses to the learning module in the field test

\begin{tabular}{|l|l|l|l|}
\hline No & Indicator & Percentage & Category \\
\hline 1 & Module contents & 81 & Very good \\
\hline 2 & Module appearance & 81 & Very good \\
\hline 3 & Material description & 56 & Enough \\
\hline 4 & Illustrations/pictures & 63 & Good \\
\hline 5 & Practical steps and procedures & 63 & Good \\
\hline Average & 68.75 & Practical \\
\hline \multicolumn{4}{|l|}{ Category: adaptation from Akbar (2013) [14] } \\
\hline
\end{tabular}

$0-20=$ not good; $21-40=$ not good; $41-60=$ good enough;

$61-80$ = good; $81-100=$ very good

Assessment of the practicality of the learning module developed based on the responses of students who have used the module in learning activities. There are two components of practicality assessment, namely the practicality of expectations and actual practicality. The practicality of expectations is obtained from the student response assessment data to the module at the small group stage. The results of the practicality of expectations showed that 100 students stated that the module was interesting in terms of content and appearance, and $83 \%$ of students stated that the material description, illustrations/pictures, and practical steps were easy to understand.

Actual practicality is obtained from the student response assessment data to the module at the field test stage. The results of the actual practicality assessment showed $81 \%$ of students agreed that the module was interesting in terms of content and appearance, $56 \%$ of students stated that the description of the material in the module was easy to understand, and $63 \%$ of students stated that illustrations or pictures and practicum instructions in the module were easy to understand. The actual practicality value in the material aspect is the lowest practicality value. This is because the material in the module is slightly different from the material presented in the 2013 curriculum science book for junior high school level and equivalent. In the module, there is material about resistor color bands that used to be in the competency-based curriculum and the education unit level curriculum. So, this material is included in enrichment material if it is brought up again in learning using the 2013 curriculum.

There is a significant difference in the assessment of the practicality of expectations and actual practicality. This shows that there is a gap in the small group test and field test. This is due to differences in the teachers who teach the two classes. Partner teachers only teach in field test classes, because of their full teaching schedules. Thus, teaching activities in small groups were replaced by other teachers.

The use of modules at each meeting with a pattern of activities and questions that lead to the emergence of science process skills, critical thinking 
skills, and critical thinking skills makes students trained in what they do. This is what ultimately is able to practice these skills because students are directly directed to carry out scientific stages in finding a fact or concept of a material.

There are still many deficiencies in the assessment of skills in research. The assessment of students' skills in practicum activities is still carried out in groups, so they cannot measure precisely how the skills of each individual student are. For this reason, improvements and improvements are needed in order to measure exactly what should be measured. Based on the explanation above, it can be concluded that the science module based on laboratory activity has achieved practicality to be used and applied to the learning process in other classes at SMPN 1 Kertak Hanyar.

\section{Effectiveness of Learning Tools}

Students are measured science process skills, critical thinking skills, and critical thinking skills at the field test stage. The observed and measured results of the assessment of science process skills, critical thinking skills, and critical thinking skills at this stage are presented in the following table.

Table-3: The results of the assessment of science process skills, skills and critical thinking skills in field tests

\begin{tabular}{|l|l|l|l|l|l|l|}
\hline No & Student & \multirow{2}{*}{ KPS } & \multicolumn{3}{|l|}{ KBK } & \multirow{2}{*}{ KmBK } \\
\cline { 4 - 6 } & Initials & & $\mathbf{1}$ & $\mathbf{2}$ & $\mathbf{3}$ & \\
\hline 1 & ABD & 3.67 & 3.22 & 3.13 & 2.71 & 2.60 \\
\hline 2 & AHR & 3.33 & 3.11 & 2.25 & 2.43 & 2.60 \\
\hline 3 & ARF & 2.78 & 3.11 & 2.25 & 2.14 & 1.20 \\
\hline 4 & ALR & 2.56 & 3.11 & 2.13 & 2.14 & 2.20 \\
\hline 5 & FTM & 2.78 & 3.11 & 2.25 & 2.43 & 1.40 \\
\hline 6 & FTR & 3.33 & 3.11 & 2.25 & 2.43 & 2.20 \\
\hline 7 & HLD & 2.78 & 3.11 & 2.25 & 2.14 & 1.60 \\
\hline 8 & HRS & 2.56 & 3.11 & 2.13 & 2.14 & 1.00 \\
\hline 9 & HSB & 2.78 & 3.11 & 2.25 & 2.43 & 1.00 \\
\hline 10 & ISK & 3.67 & 3.22 & 3.13 & 2.71 & 1.60 \\
\hline 11 & KNY & 2.78 & 3.11 & 2.25 & 2.14 & 3.00 \\
\hline 12 & MFM & 2.56 & 3.11 & 2.13 & 2.14 & 1.00 \\
\hline 13 & MFS & 3.67 & 3.22 & 3.13 & 2.71 & 2.20 \\
\hline 14 & MGP & 3.33 & 3.11 & 2.25 & 2.43 & 2.40 \\
\hline 15 & MHD & 2.78 & 3.11 & 2.25 & 2.14 & 1.40 \\
\hline 16 & MNR & 2.56 & 3.11 & 2.13 & 2.14 & 1.00 \\
\hline 17 & MSN & 2.78 & 3.11 & 2.25 & 2.43 & 2.20 \\
\hline 18 & MLD & 3.67 & 3.22 & 3.13 & 2.71 & 2.40 \\
\hline 19 & PNL & 3.33 & 3.11 & 2.25 & 2.43 & 2.60 \\
\hline 20 & RHM & 2.56 & 3.11 & 2.13 & 2.14 & 2.20 \\
\hline 21 & RSH & 2.78 & 3.11 & 2.25 & 2.43 & 1.20 \\
\hline 22 & RDA & 3.67 & 3.22 & 3.13 & 2.71 & 1.60 \\
\hline 23 & RHK & 3.33 & 3.11 & 2.25 & 2.43 & 1.60 \\
\hline 24 & RDW & 2.78 & 3.11 & 2.25 & 2.14 & 1.80 \\
\hline 25 & SYN & 2.56 & 3.11 & 2.13 & 2.14 & 1.00 \\
\hline 26 & SLR & 2.78 & 3.11 & 2.25 & 2.43 & 2.00 \\
\hline 27 & TSY & 3.67 & 3.22 & 3.13 & 2.71 & 2.40 \\
\hline 28 & TMW & 3.33 & 3.11 & 2.25 & 2.43 & 2.60 \\
\hline Average & 3.04 & 3.13 & 2.41 & 2.38 & 1.86 \\
\cline { 1 - 4 } & & 2.64 & & \\
\hline Category & Good & Moderate & Not \\
\hline & & & & & & Good \\
\hline
\end{tabular}

Note:

KPS = science process skills (doing experiments)

$\mathrm{KBK}=$ critical thinking skills

$1=$ collect data

2 = analyze data

$3=$ make a conclusion

$\mathrm{KmBk}=$ critical thinking skills (solving HOTS questions)

Category: $<2$ = not good; $2-3=$ moderate; $3-4=$ good; 4 = very good (adaptation Nur, 2014)

The learning module developed will be categorized as effective if the module is able to achieve the research objectives or has more value than the existing modules. Based on this, the developed module is designed with the aim of being able to measure student learning outcomes including cognitive learning outcomes, science process skills, and critical thinking skills, and students' critical thinking skills.

SMPN 1 Kertak Hanyar determines completeness criteria in science subjects with a minimum score of 70 . The data on the results of student knowledge tests on electrical material shows that only 7 out of 28 students get the predicate of completeness with the lowest score of 72 and the highest score of 96. Before carrying out learning it is known The class average score was 22.14 and after participating in learning the class average value increased to 59.14. The difference in the pre-test and post-test scores of students can be seen in the following figure.

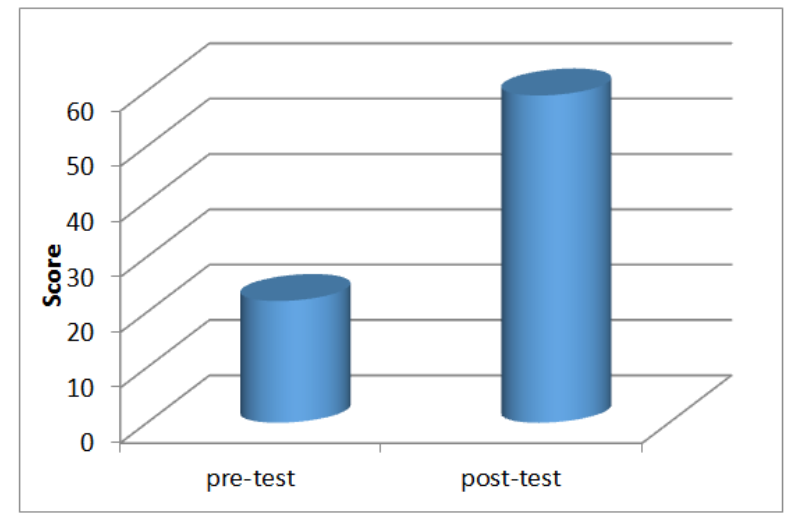

Fig-2: The difference between the pre test and post test scores

Figure 2 shows the difference in the value of students' knowledge before and after using learning with the developed module. The post test results showed that only 7 people got complete results, while the other students still scored below the KKM set by the school, which was 70 . Following up on these results, a remedial was held for students who had not yet completed it. Remedials are carried out after learning activities are carried out on material that is considered difficult. Student learning outcomes have increased, after implementing remedials, and exceeding the 
Arisa Desfiyani et al., J Adv Educ Philos, Nov, 2020; 4(11): 446-452

minimum classical completeness limit by reaching $96 \%$. Based on these results, it can be said that the developed module is effective for classroom use. This is in line with the results of research by Zaini [15] which reports that effective learning plans are used based on (1) student learning outcomes (products and processes) that have exceeded classical completeness, (2) excellent student performance skills, (3) student character behavior (discipline). and responsibility) is very good, (4) students 'social skills (collaborating and contributing ideas) are mostly very good, and (5) students' critical thinking skills are good.

Even though it can be said to be effective, only $25 \%$ of students complete the electrical material (based on post test results). This is because the cognitive knowledge items only passed the logical validity test stage. Based on the expert's assessment, the questions consisting of 10 items of true-false type and 5 items of multiple choice can be used for learning activities because they are in accordance with the learning indicators. Problems with true-to-false types are questions of the lower-order thinking type with levels $\mathrm{C} 1$ to $\mathrm{C} 3$, while multiple choice questions are questions of higher-order thinking with levels $\mathrm{C} 4$ and C5. This problem has not been tested for empirical validity, so it is not known whether the questions have met the criteria for validity and reliability of the items.

Various obstacles arise in the implementation of learning using a laboratory activity-based module at the field test stage. Students who are not familiar with various electrical components are awkward at first, so they look very careful in using them. After carrying out practical activities several times, students began to get used to it and had no difficulty using these tools. However, the condition of the electrical equipment becomes another obstacle. The circuit board is loose, the wire on the lamp is broken due to the pulling force of students who are too enthusiastic to release the components from the circuit board, to loosening the poles of the multimeter. This of course affects the results of practicum, students have difficulty in retrieving data and measurement results that are not precise also make it difficult for students to conclude research results. The result of this condition is the delay in learning time because curious students want to get better results doing lab work repeatedly. This condition is in line with Soviani [16] stated that the concept of learning through laboratory activities takes a relatively long time so it is less precise if the time used is limited.

The advantage of the developed module is the number of practicum activities provided in the module. Almost all knowledge in the module is obtained through the findings of practicum results. So that by experiencing yourself and being actively involved in learning will leave a meaningful learning impression on students. Susilawati [17] states that direct experience through independent learning activities and experiments can improve understanding of basic concepts that can construct students' analytical skills to solve complex problems. The questions presented in the evaluation section in the module are high-level questions, C4 and C5 according to Bloom's taxonomy, which, if the students have mastered the basic concepts, will be very helpful in solving national exam questions. In line with the research results Zaini [15] reported the results showed that student worksheets could be used effectively based on: 1) critical thinking skills of MIPA MAN Kapuas students which were classified into good categories such as defining problems, making hypotheses, collecting data, analyzing data and make conclusions, 2) there are signs of increased critical thinking skills, except for the skills to make conclusions.

In general, it can be concluded that the module development results are effectively used in the learning process, but improvements are still needed to produce modules that meet educational requirements and goals. Learning science by using the developed module strives to provide stimulation and information that is structured and well-organized and attractive so that students are motivated to gain learning experiences according to their respective conditions, characteristics, and cognitive levels. This is in line with constructivism theory that with existing experience and knowledge, ideas or concepts received through oneself, and by interacting with other people or the media, it will provide opportunities for students to gain as much learning experience as possible. in building newly acquired knowledge, ideas, or concepts.

\section{CONCLUSION}

Based on the results of research on the development of a laboratory activity-based science learning module on electrical material, the following conclusions are obtained.

1. Module development results are valid based on six aspects of assessment, namely module design, organization and language, material, format, presentation, and support for innovation and quality improvement of teaching and learning activities. This validity is supported by student opinion through the module readability test.

2. The practical development result module is based on five aspects of assessment, namely the attractiveness of the content, the attractiveness of the appearance, the ease of description of the material, the ease of illustrations or pictures, and the ease of practicum steps.

3. The module of effective development results is based on four aspects of assessment, namely cognitive learning outcomes, science process skills, critical thinking skills, and critical thinking skills.

\section{REFERENCES}

1. Susilowati, S., \& Ramli, M. (2017, October). Analisis keterampilan berpikir kritis siswa 
madrasah aliyah negeri di kabupaten magetan. In Seminar Nasional Pendidikan Sains (Vol. 21, pp. 223-231).

2. Kuswana, W. S. (2013). Taksonomi Berpikir. Bandung: Remaja Rosdakarya.

3. Karim., \& Rahmalia, D. (2017). Kemampuan Berpikir Kritis Siswa dalam Pembelajaran Matematika dengan Menggunakan Model Reciprocal Teaching di SMA Negeri 1 Rantau. Edu-Mat: Jurnal pendidikan Matematika, 5(2). in http://ppjp.ulm.ac.id/journal/index.php/ edumat/article/download/4643/4043, accessed on 13 Juni 2019.

4. Suriasa. (2005). Dasar-Dasar Pendidikan Fisika. Catatan Kuliah tidak dipublikasikan. Banjarmasin: FKIP ULM.

5. Agustina, M. (2018). Peran Laboratorium Ilmu Pengetahuan Alam (IPA) dalam Pembelajaran IPA Madrasah Ibtidaiyah (MI)/Sekolah Dasar (SD). At-Ta'dib: Jurnal Ilmiah Pendidikan Agama Islam, Vol. 10 No. 1, in http: //ejournal.staindirundeng.ac.id/index.php/tadib/arti cle/download/110/72/, accessed on 16 Desember 2018.

6. Rosada, D., Kadarisman, N., \& Raharjo. (2017). Panduan Pengelolaan dan Pemanfaatan Laboratorium IPA. Jakarta: Kemendikbud.

7. Hermita, R. (2016). Pengembangan Modul Berbasis Bounded Inquiry Laboratory (Lab) untuk Meningkatkan Literasi Sains Dimensi Proses pada Materi Sistem Pencernaan Kelas XI. Online, in https://jurnal.fkip.uns.ac.id/index.php/inkuiri/articl e/view/9667, accessed on 4 Desember 2018.

8. Akbar, S. (2017). Instrumen Perangkat Pembelajaran. Bandung: PT Remaja Rosdakarya.

9. Yanti, I. W. (2016). Pengembangan Modul Berbasis Guided Inquiry Laboratory (GIL) untuk Meningkatkan Literasi Sains Dimensi Konten. Inkuiri: Jurnal Pendidikan IPA, in https://jurnal.fkip.uns.ac.id/index.php/inkuiri/ article/view/9668, accessed on 4 Desember 2018.
10. Sanjaya, R. W. K. (2017). Pengembangan Modul Berbasis Bounded Inquiry Lab untuk Meningkatkan Literasi Sains Dimensi Konten pada Materi Sistem Pencernaan Kelas XI. Inkuiri: Jurnal Pendidikan IPA, in https: //jurnal.uns.ac.id/inkuiri/article/view/17828, accessed on 4 Desember 2018.

11. Pratiwi, H. E. (2014). Pengembangan Modul Pembelajaran Biologi Berbasis Hybrid Learning untuk Meningkatkan Kemampuan Berpikir Kritis dan Hasil Belajar Siswa Kelas XI. SKRIPSI Jurusan Biologi-Fakultas MIPA UM.

12. Misniyati, A., Zaini, M., \& Kaspul. (2016). Process and Performance Skills of Grade X Madrasah Aliyah Students in Learning of Concept of Archaebacteria and Eubacteria Prosiding Seminar Nasional Lahan Basah Tahun 2016 Jilid 2: 695-702 ISBN: 978-602-6483-34-8. Lembaga Penelitian dan Pengabdian kepada Masyarakat, Universitas Lambung Mangkurat 695.

13. Suryawati, E. (2017). Pengembangan Lembar Kerja Siswa Biologi SMA Berbasis Pendekatan Ilmiah untuk Meningkatkan Keterampilan Berfikir Siswa. Jurnal Pendidikan Biologi, 6(2), 91-99.

14. Akbar, Sa'dun. (2013). Instrumen Perangkat Pembelajaran. Bandung: Remaja Rosdakarya.

15. Zaini, M. (2019). Keefektivan Lembar Kerja Siswa Pada Konsep-Konsep Biologi Jenjang Madrasah Aliyah (Suatu Penelitian Desain Pendidikan). Bioedukasi: Jurnal Pendidikan Biologi, 12(1), 20-29.

16. Soviani. (2017). Belajar dari Aktivitas Laboratorium. Online, in http://integrasi. science/belajar-dari-aktivitas-laboratorium/, accessed on 16 Desember 2018.

17. Susilawati. (2015). Pembelajaran Real Laboratory dan Tugas Mandiri Fisika pada Siswa SMK Sesuai dengan Keterampilan Abad 21. Jurnal Pendidikan Fisika Indonesia, 11(1), in https://journal.unnes.ac.id/nju/ index.php/JPFI/article/view/4005, accessed on 13 Juni 2019. 